\title{
Study of Heavy Metal Contaminations in Green Leafy Vegetables and Fruits of Kitwe District, Zambia
}

\author{
John Siame*, Kabanda Masenga, James Mulwanda \\ Department of Chemical Engineering, Copperbelt University, Kitwe, Zambia \\ Email address: \\ jsiamem@yahoo.co.uk (J. Siame) \\ ${ }^{*}$ Corresponding author \\ To cite this article: \\ John Siame, Kabanda Masenga, James Mulwanda. Study of Heavy Metal Contaminations in Green Leafy Vegetables and Fruits of Kitwe \\ District, Zambia. International Journal of Environmental Protection and Policy. Vol. 4, No. 5, 2016, pp. 120-125. \\ doi: 10.11648/j.ijepp.20160405.12
}

Received: July 7, 2016; Accepted: August 5, 2016; Published: August 30, 2016

\begin{abstract}
The heavy metal concentrations of $\mathrm{Cu}, \mathrm{Ni}, \mathrm{Zn}, \mathrm{Co}, \mathrm{Pb}$ and $\mathrm{Fe}$ in fruits - Eggplant (Solanum melongena), Lemon (Citrus limon), Tomato (solanum lycopersicum) and Green Leafy Vegetables (GLV) - Pumpkin Leaves (telfairia occidentalis), Rape (brasicca napus), were analyzed. GLV and fruits were purchased from four different market locations (Chamboli, Chisokone, Chimwemwe and Chipata markets) located in and around Kitwe District, Zambia. The heavy metal concentrations in GLV and fruits were determined using the Perkin-Elmer 2380 Atomic Absorption Spectrophotometer (AAS). Most of the results obtained from the analysis showed high levels of heavy metal concentrations as compared to standards permissible by World Health Organization (WHO) and Food and Agriculture Organization (FAO). The levels of heavy metal concentrations in GLV ranged from 1.40 to $7.80 \mathrm{mg} / \mathrm{kg} \mathrm{Fe} ; 0.50$ to $4.10 \mathrm{mg} / \mathrm{kg} \mathrm{Cu} ; 0.35$ to $4.0 \mathrm{mg} / \mathrm{kg} \mathrm{Co} ; 2.00$ to $9.00 \mathrm{mg} / \mathrm{kg} \mathrm{Ni} ; 0.70$ to 5.05 $\mathrm{mg} / \mathrm{kg} \mathrm{Zn} ; 0.40$ to $1.10 \mathrm{mg} / \mathrm{kg} \mathrm{Pb}$, while for fruits the levels ranged from 1.30 to $7.50 \mathrm{mg} / \mathrm{kg} \mathrm{Fe} ; 0.50$ to $3.20 \mathrm{mg} / \mathrm{kg} \mathrm{Cu} ; 0.50$ to $4.00 \mathrm{Co} ; 1.17$ to $5.10 \mathrm{mg} / \mathrm{kg} \mathrm{Ni} ; 0.20$ to $1.25 \mathrm{mg} / \mathrm{kg} \mathrm{Zn}$ and 0.18 to $0.50 \mathrm{mg} / \mathrm{kg} \mathrm{Pb}$. The high levels of heavy metal concentrations in most of the GLV and fruits could be attributed to the various anthropogenic activities taking place in the four locations, with mining activities being the most common contributor. However, if not controlled or monitored by local authorities, the health effects that come with consuming contaminated food may be fatal.
\end{abstract}

Keywords: Atomic Absorption Spectrophotometer, Concentrations, Contaminations, Fruits, Green Leafy Vegetables, Heavy Metals

\section{Introduction}

In Zambia, there is a well-developed mining sector which is the backbone of the economy. The mining sector is dominated by $\mathrm{Cu}$ and $\mathrm{Co}$ production. The country is also among the major producers of gem-quality emerald, a variety of mineral commodities for the construction industry, and other gemstones (primarily amethyst, beryl, aquamarine and tourmaline) and has a high potential of coal production.

Kitwe District is the Zambian's third largest city. It is located in the central part of the Copperbelt Province and is endowed with vast natural resources, including forests. Kitwe District has a population of 517, 543 representing 26.2 percent of the total population of the Copperbelt Province. The main core economic activity of the district is mining and mining-oriented activities. The major minerals mined in the district are $\mathrm{Cu}$ and $\mathrm{Co}$. It is also a major producer of gemquality emerald [1-3]. In recent past, the people of Kitwe District have engaged in vegetable and fruit cultivation in order to feed the ever growing population of the district and also to earn some income for their families. These small scale farmers in and around Kitwe District are the main suppliers of vegetables and fruits required in the district markets. These fields and farms are usually irrigated either with water from rivers which are polluted by mine effluents or streams contaminated with raw sewerage water.

Therefore, the purpose of this study was to investigate the heavy metal contaminations $(\mathrm{Cu}, \mathrm{Ni}, \mathrm{Zn}, \mathrm{Co}, \mathrm{Pb}$ and $\mathrm{Fe})$ in Green Leafy Vegetables (GLV) and fruits from selected markets in and around Kitwe District and evaluates the levels of heavy metal concentrations in different GLV and fruits. 
Fresh fruits and GLV are of great importance in the diet because of the presence of vitamins and mineral salts. In addition, they contain water, calcium, iron, sulphur and potash [4]. They constitute an important part of human diet since they contain carbohydrates, proteins, vitamins, minerals and fibers required for human health. They also act as neutralizing agents for acidic substances formed during digestion [5]. Therefore, fruits and GLV are very important class of food and are very useful for the maintenance of health and as preventive treatment of various diseases [6]. However, these food items are known to contain both essential and toxic metals over a wide range of concentrations. As human activities increases, especially with the application of modern technologies, pollution and contamination of human food chain has become inevitable. In particular, human exposure to heavy metals has risen dramatically in the last 50 years as a result of an exponential increase in the use of heavy metals in industrial processes and products. Heavy metals have been reported to have positive and negative roles in human life [7-10]. Cadmium, lead and mercury are major contaminants of food supply and may be considered the most important problem to our environment while others like iron, zinc and copper are essential for biochemical reactions in the body [11]. Although these may be essential, an excessive amount over time may have serious health implications. Additionally, fruits and GLV are generally safe for dietary consumption but accumulation of their contaminants in the bodies of the consumers over a long period of time is of major concern as it can result to serious health conditions.

Furthermore, large amount of waste substances, effluents and chemicals are introduced into the environment through several sources such as mines and processing industries. Some of these substances contain heavy metals such as cadmium, lead, copper, mercury nickel, zinc and cobalt, which are known to be toxic to man and animals. Generally, most heavy metals are not biodegradable; they have long biological half-lives and have the potential for accumulation in the different body organs leading to unwanted side effects $[12,13]$. The world wide campaign for the promotion of a green environment is therefore a very timely one.

The content of essential elements in plants is conditional, the content being affected by the characteristics of the soil and the ability of plants to selectively accumulate some metals [14]. In addition to the soil, other sources of heavy metals for plants are: rainfall in atmospheric-polluted areas, traffic density, use of oil or fossil fuels for heating, atmospheric dusts, plant protection agents and fertilizers, which could be absorbed through aerial parts such as the fruits and leaves [15-17]. These plant materials could also be contaminated by various substances including trace metals as farmers wash them with contaminated water before bringing them into the market. Some of these elements are toxic to humans even at a very low level. Excessive content of $\mathrm{Pb}$ and $\mathrm{Cd}$ metals in food is associated with etiology of a number of diseases especially with cardiovascular, kidney, nervous as well as bone diseases [18-20].
The study therefore, sought to qualitatively and quantitatively establish possible heavy metal contamination of most consumed fruits and GLV in and around Kitwe District of Copperbelt Province with a view to compare the results with those available in literature and the tolerable limits of $\mathrm{WHO} / \mathrm{FAO}$ recommendations.

\section{Experimental Procedure}

\subsection{Sample Collection}

GLV and Fruits were purchased from four markets sites viz. Chamboli (Market 1), Chipata (Market 2), Chimwemwe (Market 3) and Chisokone (Market 4) located in and around Kitwe District, Zambia. Four markets were randomly selected giving priority to markets situated near the mining areas. Market Site 1, 3 and 4 were selected from highly populated areas which are near the copper mines, while Market Site 2 was selected from low populated area near the Kafue River. The GLV purchased were Pumpkin leaves (Telfairia occidentalis), Rape (Brasicca napus), and fruits purchased were Eggplant (Solanum melongena), Lemon (Citrus limon), and Tomato (Solanum lycopersicum). GLV and fruits samples were collected in clean polyethylene bags and brought to the laboratory for analysis.

\subsection{Sample Preparation and Analysis}

\subsubsection{Treatment of Samples}

GLV and fruits samples from market sites were washed thoroughly with running tap water as prevalent during normal cooking process, to remove soil particles, dirt and other airborne pollutants. The edible parts were chopped into small pieces.

\subsubsection{Drying of Samples}

The test samples were dried in a drying oven at $105^{\circ} \mathrm{C}$ until a constant weight was obtained. The samples were then cooled to ambient temperature, crushed by means of a clean pestle and ceramic mortar to obtain homogenized samples. The ground samples were then stored at room temperature in airtight sealed polyethylene bags until required for analysis by Atomic Absorption Spectrophotometer (AAS) after dry ashing technique as described in AOAC 999.11 [21].

\subsection{Instrumentation}

Heavy metal concentrations were determined on a PerkinElmer 2380 Atomic Absorption Spectrophotometer (AAS). The results of each sample represent an average of three replicate readings. Calibration curves of absorbance versus concentration were plotted for each heavy metal and the concentration of each metal was determined from the calibration plot by interpolation [22].

\subsection{Quality Assurance}

Appropriate safety measures and quantity assurance procedures were followed to ensure the reliability of the test results. All the chemicals and reagents used were of 
analytical and trace metal free grades. Properly cleaned glassware, utensils and distilled water were used during the research project. Samples were carefully handled to minimize the cross-contaminations and reagent blank determinations were carried out in order to correct the instrument readings.

\subsection{Sample Digestion}

About $2 \mathrm{~g}$ of the ground of each GLV and fruit samples were weighed and digested with $1 \mathrm{~mL}$ concentrated $\mathrm{HClO}_{4}, 5$ mL concentrated $\mathrm{HNO}_{3}$ and $0.5 \mathrm{~mL}$ concentrated $\mathrm{H}_{2} \mathrm{SO}_{4}$ in a $50 \mathrm{~mL}$ Kjeldahl flask. The blank sample was prepared by repeating the same procedure but omitting the GLV and fruit sample. The concentrations of $\mathrm{Fe}, \mathrm{Cu}, \mathrm{Co}, \mathrm{Ni}, \mathrm{Zn}$ and $\mathrm{Pb}$ were determined using an AAS.

\section{Results and Discussion}

Table 1 and 2 indicates the variations of heavy metal concentrations and moisture content (\%) studied in GLV and fruits collected from four different locations. The GLV and fruits collected are the commonly consumed in and around Kitwe District, Zambia. The results are the averages of the three replicates tested on GLV and fruits. The heavy metal concentrations determined were based on the GLV and fruits dry weights. Furthermore, the results obtained from the analysis were compared with the set standards agreeable by $\mathrm{FAO} / \mathrm{WHO}$ in a general session that was convened to establish various concentrations of toxic substance in foods [23].

According to Table 1, the average concentrations of heavy metals detected in GLV collected from the four market sites ranged from $1.40-7.80 \mathrm{mg} / \mathrm{kg}$ for $\mathrm{Fe}, 0.50-4.10 \mathrm{mg} / \mathrm{kg}$ for $\mathrm{Cu}$, $0.35-4.00 \mathrm{mg} / \mathrm{kg}$ for $\mathrm{Co}$, and $2.00-9.00 \mathrm{mg} / \mathrm{kg}$ for $\mathrm{Ni}, 0.70-$ $5.05 \mathrm{mg} / \mathrm{kg}$ and $0.40-1.10 \mathrm{mg} / \mathrm{kg}$ for $\mathrm{Pb}$ on dry matter basis, while in Table 2, the average concentrations of heavy metals detected in fruits collected from the four markets sites ranged from $1.30-7.50 \mathrm{mg} / \mathrm{kg}$ for $\mathrm{Fe}, 0.50-2.00 \mathrm{mg} / \mathrm{kg}$ for $\mathrm{Cu}, 0.50$ $4.00 \mathrm{mg} / \mathrm{kg}$ for Co, $1.17-5.10 \mathrm{mg} / \mathrm{kg}$ for $\mathrm{Ni}, 0.20-0.70 \mathrm{mg} / \mathrm{kg}$ and $0.18-1.00 \mathrm{mg} / \mathrm{kg}$ for $\mathrm{Pb}$ on dry matter basis. The concentration levels of $\mathrm{Pb}$ were observed to be the lowest for both GLV $(0.40-1.10 \mathrm{mg} / \mathrm{kg})$ and fruit $(0.18-1.00 \mathrm{mg} / \mathrm{kg})$ samples. The concentration levels of $\mathrm{Fe}$ and $\mathrm{Ni}$ were observed to be highest in GLV $(1.40-7.80 \mathrm{mg} / \mathrm{kg}$ for Fe, and $2.00-9.00 \mathrm{mg} / \mathrm{kg}$ for $\mathrm{Ni}$ ) while in the fruits samples, the concentration levels which were observed to be the highest were that of $\mathrm{Cu}$ and $\mathrm{Fe}(0.50-2.00 \mathrm{mg} / \mathrm{kg}$ for $\mathrm{Cu}$ and 1.30 $7.50 \mathrm{mg} / \mathrm{kg}$ for $\mathrm{Fe}$ ). Based on the results, the average concentrations of heavy metals in four market sites can be ranked in the increasing order as $\mathrm{Pb}<\mathrm{Cu}<\mathrm{Co}<\mathrm{Zn}<\mathrm{Fe}<\mathrm{Ni}$ and $\mathrm{Pb}<\mathrm{Zn}<\mathrm{Co}<\mathrm{Cu}<\mathrm{Ni}<\mathrm{Fe}$ for GLV and fruits, respectively (Figure 1 and 2). It was found that the heavy metals $(\mathrm{Cu}, \mathrm{Ni}$, $\mathrm{Zn}, \mathrm{Co}, \mathrm{Pb}$ and $\mathrm{Fe}$ ) of GLV and fruits obtained from the selected four market sites exceeded the safe limits established by FAO/WHO for human consumption (Table 1 and 2), thereby causing potential health risks to the human healthy. Furthermore, the results indicated that a clear difference in heavy metal $(\mathrm{Cu}, \mathrm{Ni}, \mathrm{Zn}, \mathrm{Co}, \mathrm{Pb}$ and $\mathrm{Fe})$ contamination exists among the different species of GLV and fruits. It has been also reported that GLV and fruit species differ widely in their ability to take up and accumulate heavy metals [24].

Heavy metals affect the nutritive values of agricultural materials and also have deleterious effect on human beings. The national and international regulations on food quality need to control concentrations of heavy metals in human food [25]. Even though $\mathrm{Cu}, \mathrm{Fe}, \mathrm{Zn}$ and $\mathrm{Ni}$ are considered as essential elements for various biological activities within the human body, high levels of these metals can affect negatively on human health. Apart from being an important bio-catalyst in the body, $\mathrm{Cu}$ is essential for body pigmentation, maintenance of the central nervous system, preventing anaemia and it is associated with the functions of $\mathrm{Fe}$ and $\mathrm{Zn}$ in the body. Most plants contain inadequate amounts of $\mathrm{Cu}$ for normal growth and are regularly provided through the application of artificial or organic fertilizers. Further, the $\mathrm{Cu}$ toxicity can induce lipid peroxidation, Fe deficiency and destruction within the body. $\mathrm{Pb}$ is non-essential toxic elements which cause carcinogenic effects and teratogenic abnormalities in human, even at very low concentrations. $\mathrm{Pb}$ has been reported as a severe cumulative body toxin which enters the body through food, air and water and cannot be eliminated by washing the vegetables. The elevated levels of $\mathrm{Pb}$ in certain GLV and fruits may also occur due to contaminants in irrigation water, soil or industrial and vehicular emission as $\mathrm{Pb}$ occurs in the fuel as anti-knocking agents [26].

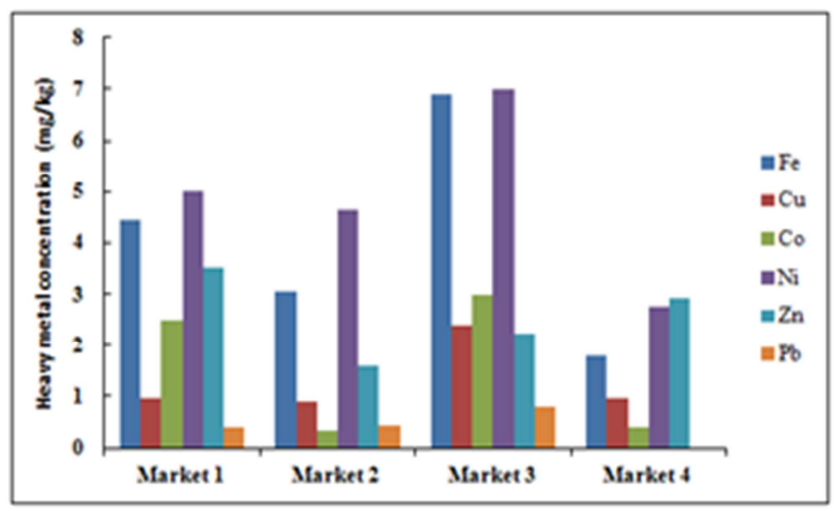

Figure 1. Average concentrations of heavy metals for combined GLV from selected market locations.

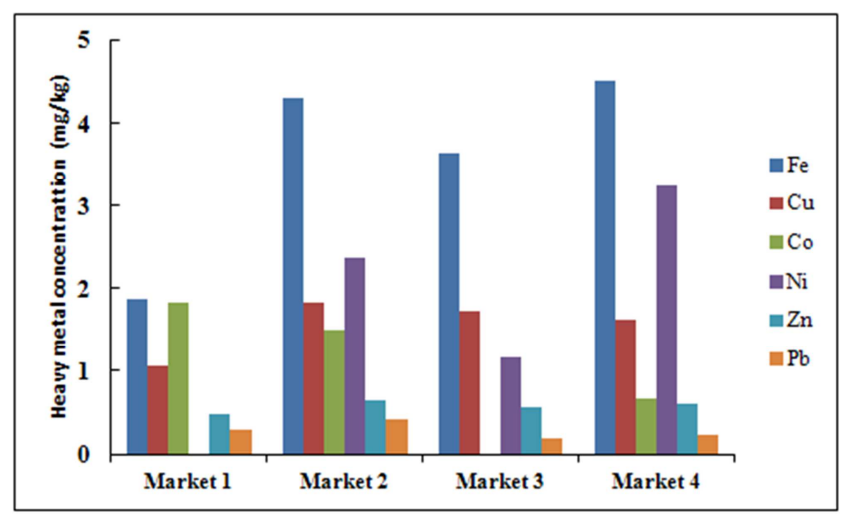

Figure 2. Average concentrations of heavy metals for combined fruits from selected market locations. 
Table 1. Heavy metal concentrations in GLV samples collected from different locations.

\begin{tabular}{lllllllll}
\hline Location & GLV & Moisture content (\%) & $\mathbf{F e}(\mathbf{m g} / \mathbf{k g})$ & $\mathbf{C u}(\mathbf{m g} / \mathbf{k g})$ & $\mathbf{C o}(\mathbf{m g} / \mathbf{k g})$ & $\mathbf{N i}(\mathbf{m g} / \mathbf{k g})$ & $\mathbf{Z n}(\mathbf{m g} / \mathbf{k g})$ & $\mathbf{P b}(\mathbf{m g} / \mathbf{k g})$ \\
\hline Market 1 & Rape & 90 & 4.20 & 0.50 & 2.00 & 2.00 & 1.95 & $<1$ \\
& Pumpkin Leaves & 88 & 4.67 & 1.40 & 3.00 & 8.00 & 5.05 & 0.80 \\
Average & & 4.44 & 0.95 & 2.50 & 5.00 & 3.50 & 0.40 \\
Market 2 & Rape & 93 & 3.50 & 1.00 & $<1$ & 3.50 & 0.70 & 0.50 \\
& Pumpkin Leaves & 91 & 2.60 & 0.80 & 0.70 & 5.75 & 2.50 & 0.40 \\
Average & & & 3.05 & 0.90 & 0.35 & 4.63 & 1.60 & 0.45 \\
Market 3 & Rape & 94 & 7.80 & 4.10 & 4.00 & 5.00 & 1.50 & 0.49 \\
& Pumpkin Leaves & 93 & 6.00 & 0.70 & 2.00 & 9.00 & 2.95 & 1.10 \\
Average & & & 6.90 & 2.40 & 3.00 & 7.00 & 2.23 & 0.80 \\
Market 4 & Rape & 89 & 1.40 & 1.40 & $<1$ & 3.50 & 3.50 & $<1$ \\
& Pumpkin Leaves & 89 & 2.20 & 0.50 & 0.80 & 2.00 & 2.34 & $<1$ \\
Average & & & 1.80 & 0.95 & 0.40 & 2.75 & 2.92 & $<1$ \\
Average* & & & 7.05 & 1.30 & 2.08 & 4.84 & 2.56 & 0.66 \\
Maximum & & 7.80 & 4.10 & 4.00 & 9.00 & 5.05 & 1.10 \\
Minimum & & 1.40 & 0.50 & 0.35 & 2.00 & 0.70 & 0.40 \\
\hline
\end{tabular}

Average*: Overall average.

Table 2. Heavy metal concentrations in fruit samples collected from different locations.

\begin{tabular}{lllllllll}
\hline Location & Fruits & Moisture content $(\%)$ & $\mathbf{F e}(\mathbf{m g} / \mathbf{k g})$ & $\mathbf{C u}(\mathbf{m g} / \mathbf{k g})$ & $\mathbf{C o}(\mathbf{m g} / \mathbf{k g})$ & $\mathbf{N i}(\mathbf{m g} / \mathbf{k g})$ & $\mathbf{Z n}(\mathbf{m g} / \mathbf{k g})$ & $\mathbf{P b}(\mathbf{m g} / \mathbf{k g})$ \\
\hline Market 1 & Tomato & 95 & 1.30 & 1.00 & 4.00 & $<1$ & 0.61 & $<1$ \\
& Eggplant & 85 & 1.30 & 1.70 & $<1$ & $<1$ & 0.48 & 0.50 \\
& lemon & 90 & 3.00 & 0.50 & 1.50 & $<1$ & 0.35 & 0.49 \\
Average & & 1.87 & 1.07 & 1.83 & $<1$ & 0.48 & 0.33 \\
Market 2 & Tomato & 85 & 4.00 & 1.30 & $<1$ & $<1$ & 0.50 & $<1$ \\
& Eggplant & 84 & 1.40 & 1.00 & 4.00 & 2.00 & 0.20 & 0.25 \\
& lemon & 88 & 7.50 & 3.20 & 0.50 & 5.10 & 1.25 & 1.00 \\
Average & & & 4.30 & 1.83 & 1.50 & 2.37 & 0.65 & 0.42 \\
Market 3 & Tomato & 88 & 7.00 & 1.70 & $<1$ & $<1$ & 0.48 & 0.50 \\
& Eggplant & 84 & 1.44 & 1.50 & $<1$ & $<1$ & 0.60 & $<1$ \\
& lemon & 91 & 2.45 & 2.00 & $<1$ & 3.50 & 0.60 & 0.05 \\
Average & & 3.63 & 1.73 & $<1$ & 1.17 & 0.56 & 0.18 \\
Market 4 & Tomato & 95 & 1.50 & 0.50 & $<1$ & 3.50 & 0.50 & $<1$ \\
& Eggplant & 85 & 7.00 & 2.40 & 1.50 & 2.00 & 0.59 & 0.50 \\
Average & lemon & 90 & 5.00 & 2.00 & 0.50 & 4.20 & 0.70 & 0.20 \\
Average* & & 4.50 & 1.63 & 0.67 & 3.23 & 0.60 & 0.23 \\
Maximum & & 3.57 & 1.57 & 2.00 & 3.23 & 0.57 & 0.44 \\
Minimum & & 7.50 & 2.00 & 4.00 & 5.10 & 0.70 & 1.00 \\
\hline
\end{tabular}

Average*: Overall average.

Table 3. Maximum levels of heavy metal concentrations in crops [23].

\begin{tabular}{lllllll}
\hline Heavy metals & $\mathbf{C u}(\mathbf{m g} / \mathbf{k g})$ & $\mathbf{F e}(\mathbf{m g} / \mathbf{k g})$ & $\mathbf{Z n ~}(\mathbf{m g} / \mathbf{k g})$ & $\mathbf{N i}(\mathbf{m g} / \mathbf{k g})$ & $\mathbf{P b}(\mathbf{m g} / \mathbf{k g})$ & $\mathbf{C o}(\mathbf{m g} / \mathbf{k g})$ \\
\hline Crops & 0.1 & 0.3 & 0.1 & 0.1 & 0.1 & 0.2 \\
\hline
\end{tabular}

Cobalt has little direct activity on its own in the body as it is an integral component of vitamin $\mathrm{B}_{12}$ and as such its effects, sources and uses are very similar to that of vitamin $\mathrm{B}_{12}$. It is involved in preventing and treating pernicious anaemia and also helps in red blood cell production. Co also supports normal nervous system functions. Very little information has been reported on its concentrations in food materials. However, for this study, its level varied between $0.35-4.00 \mathrm{mg} / \mathrm{kg}$; and $0.50-4.00 \mathrm{mg} / \mathrm{kg}$ for GLV and fruits, respectively.

The high concentrations of heavy metals in the GLV and fruits collected in four different locations could be attributed to differences in anthropogenic activities, like mining activities, different farming practices such as excessive usage of fertilizers, herbicides and other agrochemicals substances as well as the use of water from rivers which are polluted by mine effluents or streams contaminated with raw sewerage water.

Tables 1 and 2 were compared with Table 3 to access the concentration levels of heavy metals with reference to the permissible limits in GLV and fruits. It was found that all the heavy metals $(\mathrm{Fe}, \mathrm{Cu}, \mathrm{Co}, \mathrm{Ni}, \mathrm{Zn}$ and $\mathrm{Pb}$ ) were in very 
high concentration levels. The GLV collected from Chamboli and Chimwemwe markets reported the highest values for the analyzed heavy metals, while fruits collected from Chisokone and Chipata markets also reported the highest values of heavy metal concentrations. With high mining activities in the mentioned areas and also the increment of traffic activities may contributes to the accumulations of heavy metals in environment. $\mathrm{Fe}, \mathrm{Cu}, \mathrm{Co}$, $\mathrm{Ni}, \mathrm{Zn}$ and $\mathrm{Pb}$ are the typical metal pollutants due to mining and traffic activities.

According to the preliminary survey conducted the GLV and fruits sold in the selected market sites were mainly collected from the fields located in and around Kitwe District. The elevated levels of heavy metals found in GLV and fruits might be closely related to the contaminated soils and irrigation water contaminated with mine effluent, raw sewerage water, fertilizer and pesticides or due to the atmospheric deposition of metals on plant surfaces during their production, transportation and marketing [27]. Uptake of heavy metals by crops is often affected upon the plant species, growth phase, type of the soil and metal species, soil condition, weather and environment [28]. Moreover, the atmospheric depositions and marketing systems of GLV and fruits play a significant role in elevating the levels of heavy metals in GLV and fruits causing potential health hazards to the consumers [29].

The present study was the first to analyse the heavy metal concentrations in GLV and fruits collected from market sites in Kitwe District of the Copperbelt Province. However, several researches have shown that high $\mathrm{Cu}$ and $\mathrm{Co}$ concentrations were observed in the Copperbelt Province. The high concentrations of $\mathrm{Co}$ and $\mathrm{Cu}$ observed in the province were considered to be the result of mining and smelting activities [30]. It has also been reported that the bedrock within the area (Copperbelt Province) contains sulphidic mineralization, rich in $\mathrm{Co}$ and $\mathrm{Cu}$, embedded in carbonate rich shale and argillite [31].

\section{Conclusions}

A study was carried to investigate the heavy metal contaminations in GLV and fruits from selected markets in and around Kitwe District, Zambia. The heavy metals investigated were $\mathrm{Fe}, \mathrm{Cu}, \mathrm{Co}, \mathrm{Ni}, \mathrm{Zn}$ and $\mathrm{Pb}$. From the results obtained, it was concluded that the heavy metal (Fe, $\mathrm{Cu}, \mathrm{Co}$, $\mathrm{Ni}, \mathrm{Zn}$ and $\mathrm{Pb}$ ) concentrations in both GLV and fruits samples from selected markets were above the permissible limits set by $\mathrm{FAO} / \mathrm{WHO}$ for human consumption. Long term consumption of heavy metals contaminated GLV and fruits may possibly cause numerous health hazards in humans. Therefore, regular monitoring of heavy metal concentrations in GLV and fruits is crucial to avoid excessive build-up of heavy metals in the human food chain. Risk assessment should pay particular attention to market cites located in close proximity to potential sources of pollution, including mining, industrial, traffic pollution and rivers contaminated with raw sewerage water. Further investigation and research should be undertaken to assess the source(s) and extend of public exposure to heavy metals in GLV and fruits in the Copperbelt Province of Zambia.

\section{Acknowledgements}

The authors would like to thank the Copperbelt University, Kitwe, Zambia for technical and financial support.

\section{References}

[1] Government of the Republic of Zambia, "Mining in Zambia", Ministry of Mines and Minerals Development, Available online:

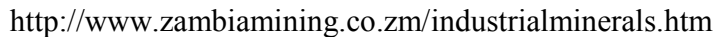
Accessed on: 06/07/2016.

[2] UN-HABITAT, "Zambia: Kitwe Urban Profile", UNON, 2009. Nairobi. Available online: www.un-habitat.org Accessed: 29/06/2016.

[3] Government of the Republic of Zambia, "2010 Summary Census Wall Chart", Central Statistical Office, 2010. Available online: www.zamstat.gov.zm/report/census/2010/Provoncial/2010Su mmaryCensusWallChart-

CopperbeltProvince.pdf.Accessed:29/06/2016.

[4] P. O. Sobukola, O. S. Awonorin, A. M. Idowu and O. F. Bamiro, "Chemical and Physical hazard profile of 'robo' processing - a street vended melon snack", International Journal of Food Science and Technology, 2010, 43 (2): 237 242.

[5] C. H. Thompson and C. W. Kelly, W. C, "Vegetable Crops", McGraw Hill Publishing Company Ltd., 1990, New Delhi.

[6] F. P. J. D'Mello, "Food safety: Contamination and Toxins", CABI Publishing, 2003, Wallingford, Oxon, UK, Cambridge, M. A., 480.

[7] C. D. Adriano, "Trace metals in the Terrestrial Environment", 1984, New York: Verlag Spiegler.

[8] U. Divrikli, S. Saracoglu, M. Soylak, and L. Elci, "Determination of trace heavy metals contents of green vegetables samples from Kayseri-Turkey by flame atomic absorption spectrometry", Fresenius Environmental Bulletin, 2003, 12: 1123-1125.

[9] S. M. Dundar and B. H. Saglam, "Determination of cadmium and vanadium in tea varieties and their infusions in comparison with 2 infusion processes", Trace Element Elect., 2004, 21: 60-63.

[10] H. Colak, M. Soylak and O. Turkoglu, "Determination of trace metal content of herbal and fruit teas of Populus nigra L. from Western Anatolia, Turkey", Journal of Environmental Biology, 2005, 26: 665-668.

[11] M. I. Zaidi, A. Asrar, A. Mansoor and A. M. Farooqui, "The heavy metal concentrations along roadsides trees of Quetta and its effects on public health", Journal of Applied Science, 2005, 5 (4): 708-711.

[12] L. Jarup, "Hazards of heavy metals contamination", Br. Med. Bulletin. 2003, 68: 167-182. 
[13] G. N. Sathawara, J. D. Parikish and K. Y. Agrwal, "Essentials heavy metals in environmental samples from western Indian", Bulletin of Environmental Contamination and Toxicology, 2004, 73: 756-761.

[14] U. Divrikli, N. Horzum, M. Soylak and L. Elci, "Trace heavy metal contents of some spices and herbal plants from Western Anatolia, Turkey", International Journal of Food Science and Technology, 2006, 41: 712-716.

[15] P. Kovacheva, R. Djingova and I. Kuleff, "On the representative sampling of plants for multi-element analysis", Phyto. Bal., 2000, 6: 91-102.

[16] A. Lozak, K. Soltyk, P. Ostapczuk and Z. Fijalek, "Determination of selected trace elements in herbs and their infusions", Science of Total Environment, 2002, 289: 33-40.

[17] M. O. Atrouse, A. S. Oran and Y. S. Al-Abbadi, "Chemical analysis and identification of pollen grains from different Jordanian honey samples", International Journal of Food Science and Technology, 2004, 39: 413-417.

[18] World Health Organization (WHO), "Cadmium". Environmental Health Criteria, Geneva, 1993, 134.

[19] World Health Organization (WHO), "Lead", Environmental Health Criteria, Geneva, 1995, 165.

[20] B. K. Steenland, "Lead and cancer in humans: where are we now?", American Journal of Industrial Medicine, 2000, 38: 295-299.

[21] Official Methods of Analysis, " $15^{\text {th }}$ Ed., AOAC", Arlington, VA, 2002, Method 999.11.

[22] M. Radojvic and N. V. Bashkin, "Practical Environmental Analysis", The Royal Society of Chemistry, Thomas Graham House, Cambridge, UK, 1999, 405-500.

[23] JOINT FAO/WHO FOOD STANDARDS PROGRAMME, "CODEX Alimentarius Committee on Contaminants in food",
The Hague, The Netherlands, ALINORM CF/5 INFO/1, 21$25^{\text {th }}$ March 2011, 1-90.

[24] H. Zhou, W. Yang, X. Zhou, L. Liu, J. Gu, W. Wang, J. Zou, T. Tian, P. Peng and B. Liao, "Accumulation of Heavy Metals in Vegetable Species Planted in Contaminated Soils and the Health Risk Assessment", International Journal ofEnvironmental Research and Public Health, 2016, 13: 289-301.

[25] A. M. Radwan and K. A. Salama, "Market basket survey for some heavy metals in Egyptian fruits and vegetables", Food Chemical Toxicology, 2006, 44: 1273-1278.

[26] T. Kananke, J. Wansapala, and A. Gunaratne, "Heavy Metal Contamination in Green Leafy Vegetables Collected from Selected Market Sites of Piliyandala Area, Colombo District, Sri Lanka", American Journal of Food Science and Technology, 2014, 2 (5): 139-144.

[27] A. Mashi, Y. I. EL-Ladan and A. Yaro, "Atmospheric contamination by heavy metals in Ilupeju industrial area of Lagos", International Journal of Current Microbiology and Applied Sciences, 2014, 3 (2): 833-840.

[28] L. F. Domergue and C. J. Vedy, "Mobility of heavy metals in soil profiles", International Environmental Chemistry, 1992, 46: $13-23$

[29] O. M. Osundiya, O. O. Ayejuyo, A. R. Olowu, A. O. Bamgboye and O. A. Ogunlola, "Bioaccumulation of heavy metals in frequently consumed leafy vegetable grown along Nigeria-Benin Seme Border, West Africa", Advanced Applied Science Research, 2014, 5 (1): 1-7.

[30] Y. Ikenaka, M. M. M. S. Nakayama, K. Muzandu, K. Choongo, H. Teraoka, N. Mizuno and M. Ishizuka, "Heavy metal contamination of soil and sediment in Zambia". African Journal of Environmental Science and Technology, 2010, 4 (11): 729-739.

[31] F. Mendelssohn, "The Geology of the Northern Rhodesian Copperbelt”. London: Macdonald \& Co., 1961. 